\title{
Kedaulatan Pangan dan Paradoks Pembangunan Pertanian
}

\section{Fuat Kurniawan - detikNews}

Program kedaulatan pangan dan produktivitas pangan memang mampu meningkatkan kuantitas jumlah produksi. Namun, tidak mengalami peningkatan pada aspek nilai produksi. Hal ini dapat kita lihat bahwa peningkatan produksi tidak berbanding lurus dengan penurunan angka kelaparan dan gizi buruk. FAO menyatakan bahwa pada 2016 setidaknya 10,7\% atau sekitar 815 juta orang di dunia mengalami gizi buruk. Demikian pula UNICEF, WHO, dan World Bank yang mengatakan bahwa pada 2017 ada sekitar 150 juta anak balita di dunia ini mengalami stunting.

Masyarakat yang mengalami kelaparan dan stunting tersebut mayoritas dari negara berkembang dan mereka dari keluarga miskin di perdesaan yang notabene dari keluarga petani gurem dan buruh tani. Permasalahan tersebut menunjukkan bahwa konsep pembangunan pertanian khususnya pertanian pangan masih memunculkan paradoks.

Pembangunan pertanian pangan hanya berorientasi pada peningkatan produktivitas hasil saja. Produksi pangan meningkat, tetapi orang kelaparan dan gizi buruk terus terjadi. Parahnya, mereka yang mengalami rawan pangan adalah petani dan buruh tani yang pada dasarnya adalah produsen pangan. Kuasa petani terhadap alat produksi makin kecil dan bertolak belakang dibandingkan dengan perusahaan dan industri. Industri tidak hanya menguasai input pertanian seperti pupuk, benih, peralatan mekanis pengolah pertanian, namun juga menguasai lahan yang sebelumnya menjadi ruang hidup petani.

Apabila kita melihat dari kebijakan pemerintah melalui anggaran yang dialokasikan untuk kedaulatan pangan memang sudah cukup besar. Pada periode tiga tahun (2014-2017) anggaran yang dialokasikan pemerintah meningkat sebesar $53,2 \%$. Pada 2014 anggaran kedaulatan pangan sebesar Rp 67,3 triliun, dan pada 2017 anggaran mencapai Rp 103,1 triliun. Lebih dari separuh dari anggaran tersebut dialokasikan untuk Kementerian Pertanian, Kementerian PU PERA, subsidi pupuk dan benih, juga untuk program Upsus Pajale (Upaya Khusus Padi, Jagung, dan Kedelai). Namun, sayangnya kebijakan dan program tersebut belum mampu mewujudkan cita-cita kedaulatan pangan.

Meskipun klaim produksi padi nasional meningkat hingga 81 juta ton pada 2017, tetapi kenyataannya impor beras terus terjadi. Tercatat pada 2015 impor beras 861 ribu ton, pada 2016 meningkat menjadi 1,3 ton, menurun pada 2017 sebesar 256 ribu ton, dan mengalami peningkatan yang drastis pada 2018 yaitu sebanyak 2 juta ton. Ketika pendapatan kaum tani mengalami kemerosotan, baik karena tingginya biaya produksi, di satu sisi dikarenakan melimpah-ruahnya impor juga menjadi pemicu jatuhnya harga produk lokal, dan harga konsumen justru bergerak naik. 
Gambaran tersebut menunjukkan fakta bahwa kekuatan utama di balik naiknya harga sarana-sarana pertanian, turunnya harga komoditi pertanian, dan tingginya harga pangan adalah adanya kontrol secara monopoli dari perusahaan-perusahaan trans-nasional.

Hal yang paling mendasar dalam kedaulatan pangan tentu saja permasalahan petani. Pangan tidak hanya soal peningkatan produksi. Program dan kebijakan kedaulatan pangan masih menjadikan petani dan buruh tani hanya sebagai objek yang justru meminggirkannya. Dalam produksi pangan, mensyaratkan adanya demokrasi ekonomi, yang berarti bahwa hak kaum tani untuk membuat keputusan dan mencari nafkah harus ditegakkan, sementara elite dan korporasi masih mendominasi pasar pangan.

Persoalan petani dan pangan tidak akan pernah usai apabila permainan harga komoditas pangan hasil pertanian yang dilakukan korporasi masih terus terjadi. Saat ini, sistem pangan dan pertanian global berada di bawah monopoli dan kekuasaan perusahaan raksasa yang berada di balik upaya "barbar" memaksakan kebijakan ekonomi neoliberal dan perdagangan bebas.

Hal tersebut tentu saja memperburuk ekosistem mata pencarian jutaan orang di perdesaan serta memperburuk wajah kemiskinan dan kelaparan yang terus terjadi. Ditambah dengan upaya meningkatkan nilai ekspor dari perkebunan-perkebunan luas dikiranya sebagai jalan terbaik untuk menghasilkan alat pembayaran luar negeri (valuta asing) yang dibutuhkan untuk mengimpor pangan. Di lain sisi, posisi Indonesia dengan WTO bersama perjanjian regional dan bilateral telah mengizinkan TNCs (perusahaan agrochemical trans-nasional) untuk memegang kekuasaan atas pasar pertanian dan pangan.

Sebenarnya, kedaulatan pangan tidak menentang adanya perdagangan global, melainkan melawan diberikannya prioritas kepada pasar sebagai wasit (pengatur dan penentu) kebijakan pertanian dan pangan. Realitas tersebut telah menunjukkan bahwa akses terhadap pasar global bukanlah solusi bagi kaum tani. Permasalahannya justru terletak pada kurangnya akses terhadap pasar lokal mereka sendiri karena telah dibanjiri oleh produk-produk luar yang lebih murah.

Alternatif jalan ketiga bagi stakeholderterkait (Kementerian Pertanian, Kementerian Perdagangan, dII) adalah membuka pasar pangan lokal yang mengakomodasi komoditas pangan hasil petani. Dalam hal ini rantai pasar distribusi yang menjadikan permainan harga komoditas perlu diatur dengan skema yang memihak pada petani sebagai produsen pangan. Tidak hanya berorientasi pada peningkatan produktivitas saja, melainkan juga orientasi program pangan yang berbasis pada komunitas dengan ditopang oleh program distribusi pangan nasional yang proaktif dan berpihak pada produsen pangan (petani dan buruh).

Pemerintah melalui kebijakannya juga harus mampu menjamin ketersediaan pangan yang cukup melalui usaha yang efisien mendapatkan pangan dari dalam negeri. Sehingga program distribusi pangan mampu menjangkau harga semua jenis pangan pokok, juga perlunya kontrol yang efektif atas harga.

Pada aspek lain, implementasi kedaulatan pangan harus mampu menempatkan kedaulatan petani sebagai tujuan utama, dan bukan menjadikan petani 
hanya sebagai alat produksi. Selain itu, perlu adanya indikator atau penanda kedaulatan pangan yang menjadi acuan semua pihak. Hal ini menjadi penting sebagai arah dan kebijakan kedaulatan pangan menjadi tersistematis dan terukur, serta menjadi panduan dan penanda bagaimana kedaulatan pangan dapat diimplementasikan.

Fuat Edi Kurniawan peneliti di Pusat Penelitian Kependudukan LIPI 